\title{
Study on 19th-century cast iron columns from the former financial office building in Kwidzyn
}

\author{
Michat Kwasek ${ }^{1}$, Aleksander Piwek ${ }^{1}$, and Robert Jankowski ${ }^{2, *}$ \\ ${ }^{1}$ Gdańsk University of Technology, Faculty of Architecture, ul. Narutowicza 11/12, 80-233 Gdańsk, \\ Poland \\ ${ }^{2}$ Gdańsk University of Technology, Faculty of Civil and Environmental Engineering, ul. Narutowicza \\ 11/12, 80-233 Gdańsk, Poland
}

\begin{abstract}
The article presents the results for cast iron columns used as floor supports in the former financial office building in Kwidzyn (Poland). The stocktaking drawings provided the general and detailed data about the 19 th century designer's decisions. During the research, architectural and structural analysis was carried out. The graphics were used as a starting material for preparing 3D calculation models. The FEM-based numerical simulations were conducted using ABAQUS software. It was shown that the selection of such a structural solution in the building allowed arranging the interior space in an innovative way. The results of the study prove the thesis put forward of a low application extent of the load-bearing capacity of cast iron column used.
\end{abstract}

\section{Introduction}

The methods to obtain metal from ores were already known many centuries BC [1], but only the 18th and the 19th century brought technological opportunities that made it possible to cast extremely resistant structural elements of iron alloy, often with beautiful decorative forms [2-5]. The popularity of this material influenced the 19th-century art, utility objects and architecture [6]. The new material was used in construction of new buildings and the old ones partially or completely rebuilt during that period [7].

In the 19th century, cast iron structural elements were frequently selected on the basis of design tables. That method made it possible to determine the required cross-sectional values based on the element span. The simplified tactic increased the efficiency of the design process significantly. It was also related to the manufacturing method of cast iron elements. Due to the technological improvements at the time, identical columns and beams could be quickly obtained. They were efficiently selected and installed in various structures. The drawback of this design method was related to the fact that the load-bearing capacity of elements was not optimized. It is difficult to determine whether the designers made a full application of cast iron resistance. A few publications deal with this issue in general (e.g. [8-13]), even less in relation to the area of Poland (e.g. [14]).

${ }^{*}$ Corresponding author: jankowr@pg.edu.pl 
Cast iron was also used to build floors of buildings in the 19th century. Metal beams (often made of cast iron) were supported on brick walls. The filling between the beams was also made of ceramic elements. Quite often, floor beams were also supported on intermediate supports in the form of cast-iron columns. All such solutions made it possible to use longer beams and obtain a spacious interior. The impression of a large space was not obliterated by intermediate supports, which, due to high compressive strength of cast iron, resulted in relatively small cross sections.

The article is focused on cast iron columns used as floor supports in the former financial office building in Kwidzyn (Poland), used now as the municipal library. This property is located at Piłsudski 21 Street, erected in the eclectic style in the decade of 1890s.

\section{Architectural analysis}

The analyzed building was originally intended for the headquarters of the financial office. It is a brick structure, three-storey high (the top storey is a applicable attic), with basement. In the symmetrical plan, it is possible to distinguish the central part with the entrance and staircase as well as two side wings (Fig. 1, Fig. 2).

\subsection{Construction solutions}

The floors were probably made of bricks with metal infills using Klein technology (no exposures were made during the site inspection). In some parts of the floor, the barrel vault is visible. In the lateral parts of the building, spacious rooms are located both on the ground floor and on the first floor. These rooms show a nearly rectangular shape, its dimensions are $7.1 \times 8 \mathrm{~m}$. Cast iron columns have been installed in pairs in their central part (see Figure 3). They underpin the binding joists providing support to other metal beams. In each room, both columns are positioned in the main beam axis, with an axial distance from each other of $84 \mathrm{~cm}$. The columns on the ground floor and first floor are above each other. Cast iron columns were partially or completely walled up in one of the rooms on the ground floor and in one of the rooms on the first floor, as a results of contemporary rebuilding. The main girder beam, supported by the columns, shows an overall length of approximately $7.4 \mathrm{~m}$ and a maximum span of $3 \mathrm{~m}$. The height of the beam is around $270 \mathrm{~mm}$. Its width of about $46 \mathrm{~cm}$ was obtained by spreading apart the metal elements and most likely filling the inbetween space between them with bricks. Such an approach brought about increasing the width of the support of the perpendicular beams.

\subsection{Columns}

The columns are $3.5 \mathrm{~m}$ high, showing a round shaft of outer diameter of $20 \mathrm{~cm}$. The decorations are modest. The columns have a clearly marked base and a capital, but they do not present any decorative band on the shaft section (Figure 3). The base, of a $25 \mathrm{~cm}$ diameter, contains a simple profiling in the upper part, which forms the boundary between it and the shaft. The capital also does not either show any rich form. Visually, it can be divided into two parts, in both parts a cylinder can be indicated. The lower part is separated within the shaft using a half-round moulding of the same diameter. At the top, it ends with a simple profile creating a socket, with a flat disc above. The second part of the capital is set on it, its construction clearly results from structural reasons. 


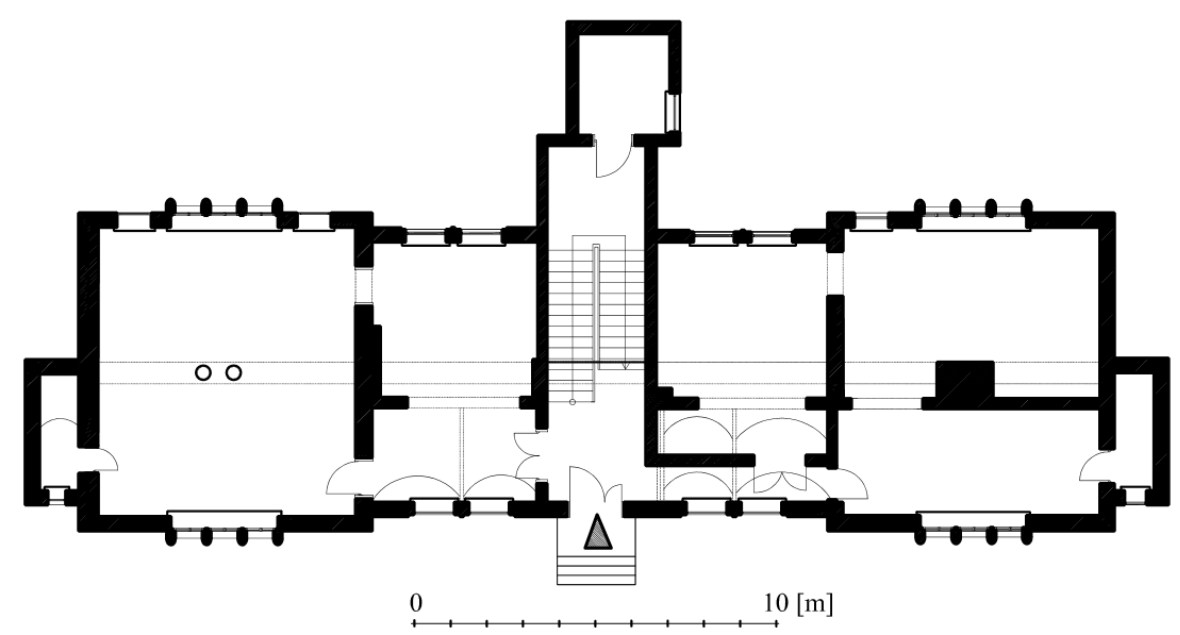

Fig. 1. Plan of the ground floor of the former financial office in Kwidzyn (stocktaking 2017).

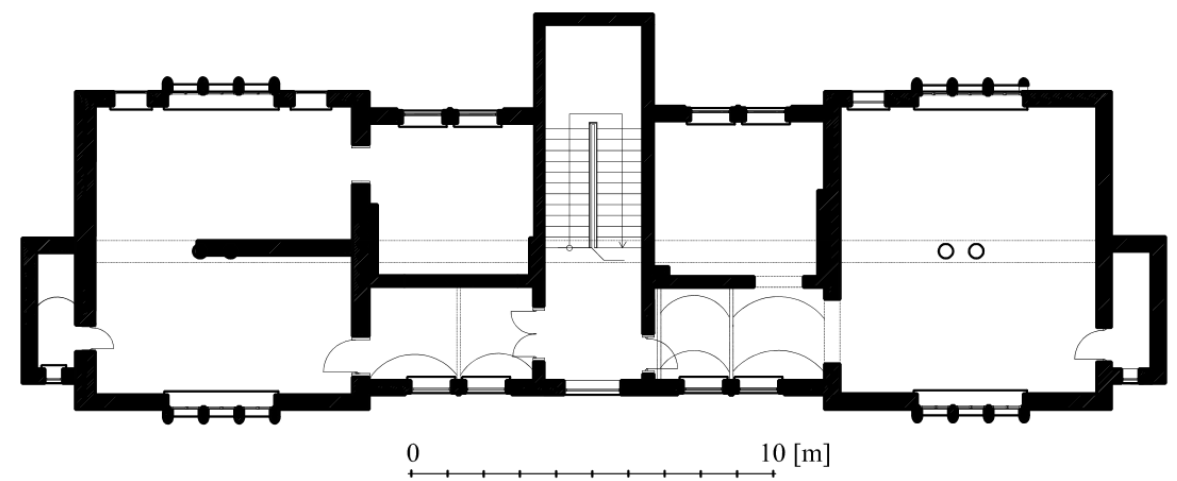

Fig. 2. Plan of the first floor of the former financial office in Kwidzyn (stocktaking 2017).

Each column is topped with a separate cast iron slab (Figure 3A) with dimensions of 26 $\mathrm{x} 48 \mathrm{~cm}$ and a thickness of $4.5 \mathrm{~cm}$. Two stiffening ribs are symmetrically added to the cylindrical element, whose diameter in this part has been increased to $24 \mathrm{~cm}$. They protrude from the cylinder on its whole height. Ribs take the form of $3 \mathrm{~cm}$ thick plates with outer curved edges which are mostly "S" shaped (Figure 3B). There is a protrusion at the connection to the plate which forms additional stiffening. The ribs are positioned along the axis of the plate parallel to its longer side. The same axis is set perpendicular to the axis of the binding joist. Such a solution makes the beam's support area bigger. All profiles, the upper plate and stiffening ribs are integral parts of the column. They were created at the stage of casting the pillar.

Increasing the diameter of the pipe (shaft) and adding stiffening elements increased additionally the load-bearing capacity of the support by securing the top plate against bending in the case of non-axial loading forces. The columns are connected to the main beam in the corners of the plate using four bolts passing through the plate and the bottom flanges of the section of the main floor beam. 

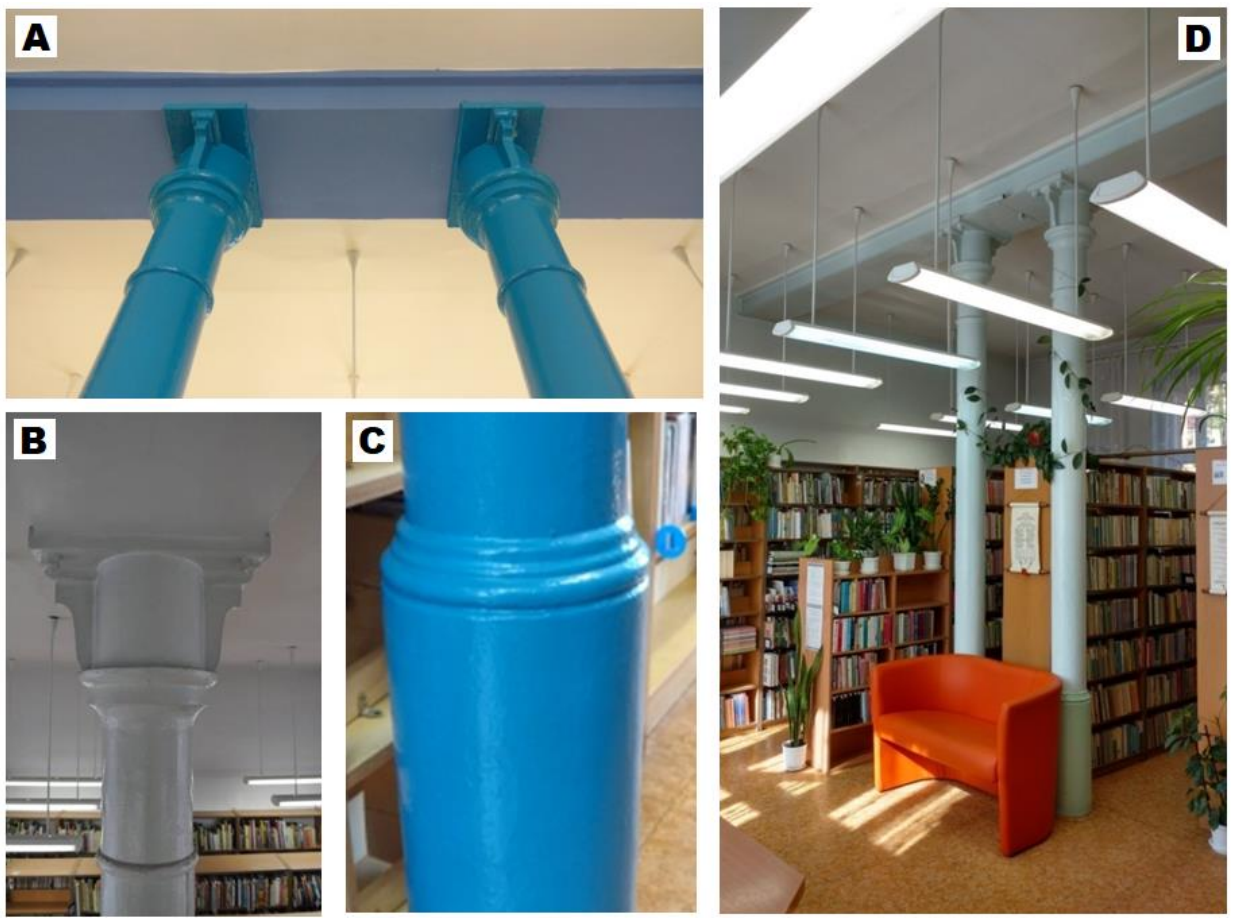

Fig. 3. Cast iron columns in the building of the former financial office in Kwidzyn: A - view of the beam's double support, B - detail of the column capital, C - base detail, D - general view.

\section{Structural analysis}

Strength calculations were carried out of the cast iron column, complemented by a simplified numerical analysis using the FEM-based ABAQUS software.

The analyzed column on the ground floor carries loads from the first floor and the usable attic. The calculation of loads was made mostly on the basis of the applicable standard PN-EN 1991-1-1 2004 [15]. The weight of the heavy-type ceramic-metal Klein floor was taken into account. The imposed load was assessed for reading and office rooms. Safety factors were applied according to the standard PN-EN 1990:2004/AC[16]. The total resultant load acting on a single column was assumed $235 \mathrm{kN}$, the actual load was uniformly distributed on the surface of the head plate. Stress check was conducted in the most critical column cross section. In the numerical analysis, the column was fully fixed at the bottom, allowing a moderate rotation of the capital.

\subsection{Numerical simulation}

The computational model has been created (see Figure 4). It can be considered the representative one for all columns used in the building. The model consists of a vertical tube (3,46 m length), a horizontal slab and stiffening ribs. The elements are fixed to each other by means of contact faces. All dimensions and profiles, defined in the numerical model, are based on the stocktaking drawings. The 8-node standard solid elements available in ABAQUS software have been used. The mesh has been created proceeding global size control. The analysis has been conducted for elements of an approximate planar area of 100 $\mathrm{mm}^{2}$ for most vertical elements, excluding the base, which showed the planar area around 
$1000 \mathrm{~mm}^{2}$. In the case of horizontal parts (plate and profiled parts of the shaft), the approximate planar area of $400 \mathrm{~mm}^{2}$ was set to the analysis. Due to the lack of exact material characteristics (no material tests were conducted due to technical limitations), the cast iron material properties were assumed based the average data typical for 19th century elements [17,18].Modulus of longitudinal elasticity was set $E=100000 \mathrm{MPa}$ while modulus of transverse elasticity $G=38000 \mathrm{MPa}$ [18] and Poisson's ratio $v=0,27$ [19].
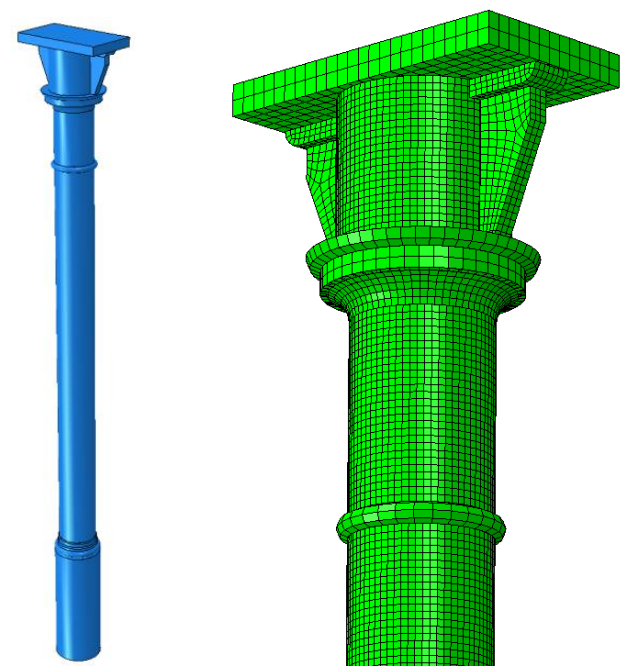

Fig. 4. The model geometry used for numerical analysis.

\subsection{Structural calculations}

In the first step of the study the column was loaded axially. The maximum compressive stresses determined in this way were used to compare them with the allowable values. In order to calculate the load-carrying capacity $\sigma_{c}$ of the cast iron column, the method developed in the second half of the 19th century by Ludwig von Tetmajer was used [17]. The method is based on the value of slenderness $\lambda$ calculated for the analyzed column as equal to:

$$
\lambda=\frac{h}{i}=\frac{351}{6,4}=54,8
$$

While the elements detect a low slenderness up to 80, the Euler's formula of critical stresses is not valid, instead the following polynomial formula should be used[18]:

$\sigma_{c}=776-12 \cdot \lambda+0,053 \cdot \lambda^{2}=776-12 \cdot(54,8)+0,053 \cdot(54,8)^{2}=277,6 \mathrm{MPa}(2)$

Additionally, the safety factor of $n=1 / 3$ was recommended [17], therefore the allowable stress $\sigma_{a}$ can be calculated as:

$$
\sigma_{a}=n \sigma_{c}=\frac{277,6}{3}=92,5 \mathrm{MPa}
$$

The calculated value is similar to the one described by Tetmajer in his monograph [17]. Established magnitudes have changed over the years, and throughout the countries. Anyway, in most of the cases they were around 80-90 MPa. 
Comparable values of allowable compressive stress were also described in German standard DIN 1051 issued in 1937 [20]. It allowed evaluating the load-bearing capacity of cast-iron elements, permissible compressive stresses for columns amounted to $90 \mathrm{MPa}$. According to this standard, stresses in a cast iron column should be determined from the formula [20]:

$$
\begin{aligned}
& \sigma=\frac{P \cdot \omega}{A} \leq \sigma_{a} \\
& \omega=\frac{\sigma_{a}}{\sigma_{b}}
\end{aligned}
$$

where $\sigma_{b}$ is the allowable stress for buckling, while the column slenderness is not higher than 80, it holds [20]:

$$
\sigma_{b}=90-0,01005 \cdot \lambda^{2}
$$

Considering the analysed column the value is:

$$
\begin{gathered}
\sigma_{b}=90-0,01005 \cdot(54,8)^{2}=59,8 \mathrm{MPa} \\
\omega=\frac{\sigma_{a}}{\sigma_{b}}=\frac{90}{59,8}=1,51
\end{gathered}
$$

The value of the maximum compressive stress in the column was also determined on the basis of a simplified numerical analysis applying the model shown in Figure 4 . In the case of axially loaded column, the maximum compressive stress was equal to $\sigma=23,91$ $\mathrm{MPa}$ (see Figure 5A). It should be noticed that the bearing capacity of the element determined on the basis of the Tetmajer method [17] significantly exceeds the actual compressive stresses, when the axial compression is assumed.

In the second stage of numerical simulations, load eccentricity was introduced. The results of the analysis indicated that the allowable compressive stresses of $90 \mathrm{MPa}$ was reached starting from the eccentricity of $16 \mathrm{~cm}$. Due to this eccentricity value, the compressive stress was as large as $92.61 \mathrm{MPa}$ (see Figure 5B).

\section{Conclusions}

The architectural and structural analysis of cast iron columns of the former financial office building in Kwidzyn (Poland) has been described in this paper. The computational investigation has been conducted using the 19th and 20th century methods, the results have been compared with the numerical analysis based on FEM.

The results of the study indicate that the low application extent of the load-bearing capacity of the cast iron column takes place while applying both historical methods. While the Tetmajer method shows around $25 \%$ the total value, the German points it at around $39 \%$. The outcome of the investigation, showing a distinctly small use of the cast iron column load-bearing capacity, is extremely important. It is because of the fact that cast iron, widely used in architecture and construction in the past, is still a little-known material. It is not in a common use for such purposes as in previous centuries, but still encountered in the historical structures. Thus the outcome of the study can be useful for the professional evaluation calculations during the adaptation of buildings for new purposes.

It should be added that the use of cast iron supports made it possible to create a more spacious interior in the analyzed building. The designers have replaced more massive brick columns that would visually divide the room. Such a solution was not desirable due to the original purpose of the structure. It was proved that cast iron columns with tubular cross 
section have high load-bearing capacity. It can be therefore confirmed that structural considerations have decided to use cast iron to provide a room with better functionality in the case of analyzed building.

The investigation described in this article was based on a number of simplifications. Therefore, further study, focused on experimental tests and numerical simulations, is planned to be conducted, so as to fully confirm the results obtained. Detailed tests on samples taken from the analyzed columns are important from the point of view of determination of material properties. After the experimental verification, the advanced nonlinear numerical analyses are also scheduled, including some stochastic issues involved (see [21-23], for example).
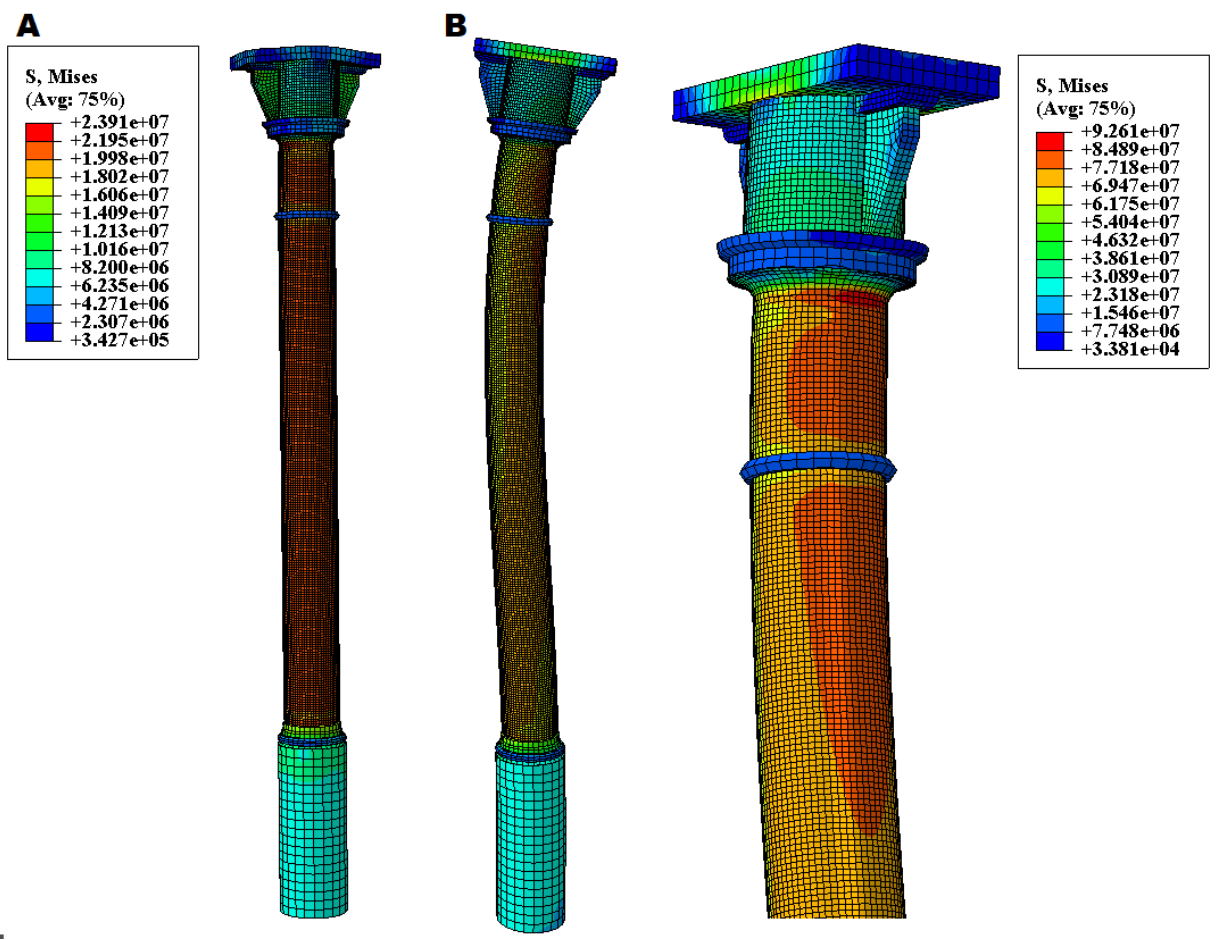

Fig. 5. Results of a simplified numerical analysis performed in ABAQUS software: A - stress map for an axially loaded column for actual loads values, B - stress map for deformed column loaded eccentrically (eccentricity of $16 \mathrm{~cm}$ ); Stress maps show equivalent stresses due to Huber-MisesHencky criterion.

The authors would like to thank TASK CI for the opportunity to use ABAQUS software.

\section{References}

1. K. Gierdziejewski, Zarys dziejów odlewnictwa polskiego (Outline of Polish foundry history), (National Technical Publishing House, Stalinogród, Poland, 1954)

2. M. Kwasek, A. Piwek, Cast iron staircase in Aleksandrów Kujawski (Poland) - history, construction, architectural form, WMCAUS, Procedia Engineering, 161, 2147-2154 (2016) 
3. M. Kwasek, A. Piwek, Lightweight glass and metal roof structures in the 19th century. Architecture and construction (XXII Lightweight Structures in Civil Engineering, Olsztyn, Poland, 31-36, 2016)

4. Ł. Lewandowski, Żeliwne schody kręcone w zespole fabrycznym Izraela Poznańskiego w Łodzi z drugiej połowy XIX wieku (Cast iron spiral stairs in the complex of Izrael Poznanski Factory in Lodz, the 2nd half of 19th century), Materiały Budowlane, 5,104105 (2017)

5. Ł. Lewandowski, Konstrukcja $i$ dekoracja schodów żeliwnych XIX wieku na wybranych przykladach (Construction and decoration of cast iron stairs of the 19th century on selected examples), Integracja sztuki i techniki w architekturze i urbanistyce (Wydawnictwo UTP, Bydgoszcz, Poland, 253-268, 2015)

6. M. Kwasek, A. Piwek, Cast iron in the $19^{\text {th }}$-century building equipment, WMCAUS, IOP Conf. Ser.: Mater. Sci. Eng., 245, 042086 (2017)

7. J. Gloag, A history of cast iron in architecture (George Allen \& Unwin, London, 1948)

8. I. Brych, M. Sýkora, Assessment of cast-iron columns using analytical models, Applied Mechanics and Materials, 821, 782-788 (2016)

9. D. Friedman, Cast-iron-column strength in renovation design, Journal of Constructed Facilities, 9(3), 220-230 (1995)

10. R. Käpplein, Untersuchung und Beurteilung alter Gußkonstruktionen, Stahlbau 66, Heft 6, 318-332 (1997)

11. B. König, W. Klingsch, Untersuchungen zur Erarbeitung eines Sicherheitskonzeptes für historische Gußeisenstützen (IRB-Verlag, 1994)

12. B. König, Historische gusseiserne Stützen - Eine zerstörungsfreies Beurteilungsverfahren für die Belastbarkeit bei Normaltemperatur und im Brandfall (Institut für Konstruktiven Ingenieurbau, Bergische Universität GH Wuppertal, 1995)

13. J. Rondal, K.J.R. Rasmusen, On the strength of cast iron columns, Journal of Constructional Steel Research, 60(9), 1257-1270 (2014)

14. J. Marcinowski, Z. Różycki, Reinforcement of existing cast-iron structural elements by means of fiber reinforced composites, CEER, 20(1), 37-45 (2016)

15. PN-EN 1991-1-1:2004, Eurocode 1: Actions on structures - Part 1-1: General actions - Densities, self-weight, imposed loads for buildings (2004)

16. PN-EN 1990:2004/AC Basis of structural design (2010)

17. L. Tetmajer, Die Angewandte Elasttizitäts und Festigkeitslehre (Franz Deuticke, Leipzig und Wien, 1905)

18. K. Czapliński, Dawne wyroby ze stopów żelaza (Former iron alloy products),(Lower Silesian Educational Publishing House, Wrocław, Poland, 21-28, 2009)

19. C. Podrzucki, Żeliwo. Struktura, właściwości, zastosowanie (Cast Iron. Structure, properties, application), t. 2 (Wydawnictwo ZG STOP, Kraków, Poland, 11-32, 1991)

20. DIN 1051. Berechnungs grundlagen für Guseisenim Hochbau, (1937)

21. R. Jankowski, H. Walukiewicz, Modeling of two-dimensional random fields, Probabilistic Engineering Mechanics, 12, 115-121 (1997)

22. J. Przewłócki, Problemy stochastycznej mechaniki gruntów. Ocena niezawodności (Dolnośląskie Wydawnictwo Edukacyjne, Wrocław, Poland, 2006)

23. P. Sorn, J. Górski, J. Przewłócki, Probabilistic analysis of a space truss by means of a multidimensional variable description, Archives of Civil Engineering, 61, 99-123 (2015) 